Revista Iberoamericana, Vol. LXXVII, Núms. 236-237, Julio-Diciembre 2011, 1019-1037

\title{
LA EXPRESIÓN DEL AMOR EN EL TIEMPO: VIOLETA, SAFO
}

\author{
POR \\ SOLEDAD FARIÑA VICUÑA \\ Universidad Diego Portales
}

\section{Algunas Consideraciones PREVias}

El presente trabajo intentará poner en relación dos poemas de amor que, aunque escritos con 27 siglos de diferencia, dan cuenta de que más allá de la construcción cultural que las diferentes sociedades hacen del amor, la expresión de un sentimiento extremo, producto directo de la experiencia, ha permanecido casi idéntica a través del tiempo. Los poemas escogidos son Con mi litigio de amor, de Violeta Parra y el fragmento 31 de Safo.

AMOR y POESÍA

El tema del amor ha dejado huellas en todas las culturas. Entre las escritas, las más inolvidables podrían ser El Cantar de los Cantares, El Banquete, El arte de amar de Ovidio, El collar de la paloma de Ibn Hazm; el Kama Sutra de Vatsyayana, por nombrar algunos. Pero ¿cómo podríamos definir el amor? O, tomando la pregunta de Julia Kristeva, “¿Hablamos de la misma cosa cuando hablamos de amor?” En su libro Historias de amor la autora intenta una definición:

Vértigo de identidad, vértigo de palabras: el amor es, a escala individual, esa súbita revolución, ese cataclismo irremediable del que no se habla más que después [...] hay que admitir [...] que, por muy vivificante que sea, el amor siempre nos quema. Hablar de él, aunque sea después, no es posible más que a partir de esta quemadura. Consecutivo al exorbitante crecimiento del Yo enamorado, tan extravagante en su orgullo como en su humildad, este desfallecimiento exquisito está en el corazón de la experiencia. (Kristeva 2-3)

Aún señalando la experiencia como fuente principal de "este vértigo", la autora acepta que le es difícil hablar de sus amores: 
Esta exaltación más allá del erotismo es dicha exorbitante tanto como puro sufrimiento: la una y el otro hacen que las palabras cobren pasión. Imposible, inadecuado, en seguida alusivo cuando querríamos que fuese muy directo, el lenguaje amoroso es un vuelo de metáforas: es literatura. Sin embargo, en lugar de abordar el tema desde la literatura, Kristeva prefiere abordarlo desde una especie de filosofía amorosa. (Kristeva 1)

En otro acercamiento, Roland Barthes reconoce -en su libro Fragmentos del discurso amoroso- la extrema soledad de este discurso, ya que a pesar de ser hablado por miles de personas, nadie lo sostiene, encontrándose separado no sólo del poder, sino también de los mecanismos que lo sostienen (ciencias, conocimientos, artes). Hablando de este libro un poco antes de su muerte, el autor reconoce que no es muy intelectual, ya que en él "uno puede proyectarse no a partir de una situación cultural sino a partir de una situación que es la situación amorosa” (énfasis mío).

Siguiendo el pensamiento de Barthes, como intelectuales reconocidos, ambos autores eligen, para hablar del amor, un discurso cercano a los mecanismos que sostienen el poder ${ }^{1} \mathrm{y}$, circundando la propia experiencia, prefieren hablar de filosofía o discurso amoroso. Sin embargo, en la introducción que titula "Elogio del amor", Kristeva habla desde su experiencia juvenil: “...el amor sería, de todos modos, solitario, ya que es incomunicable. Como si en el preciso instante en que el individuo se descubriera intensamente verdadero, extremadamente subjetivo, pero violentamente ético por cuanto está generosamente dispuesto a hacerlo todo por el otro, descubriera también el cierre de su condición y la impotencia de su lenguaje” (Kristeva 2-3).

Y es precisamente lo que Kristeva llama "impotencia de su lenguaje” el punto que nos dará la clave para iniciar el acercamiento entre el amor y el discurso más alejado de los mecanismos del poder: la poesía. Para ello nos hemos apoyado principalmente en dos textos: El amor y el origen de la poesía de Silvio Mattoni y La llama doble. Amor y erotismo, de Octavio Paz.

En La llama doble hay una distinción importante para nuestra reflexión, y es la que hace Paz entre "el sentimiento amoroso y la idea de amor adoptada por una civilización y una época”. Siguiendo a Denis de Ruougemont en su libro El amor y occidente, el autor pensaba que el sentimiento del amor, como lo conocemos, era exclusivo de la civilización occidental y se había iniciado con el amor provenzal

Hoy me parece insostenible esa opinión. Ante todo, debe distinguirse entre el sentimiento amoroso y la idea de amor adoptada por una civilización y una época. El

\footnotetext{
1 Menos cercano en el caso de Barthes, ya que él escoge un discurso fragmentario para señalar la soledad del discurso amoroso, pensando, además, que a pesar de haber tenido muchos lectores tras su aparición, este libro será el primero en ser olvidado.

Revista Iberoamericana, Vol. LXXVII, Núms. 236-237, Julio-Diciembre 2011, 1019-1037 ISSN 0034-9631 (Impreso) ISSN 2154-4794 (Electrónico)
} 
primero pertenece a todos los tiempos y lugares; en su forma más simple e inmediata no es sino la atracción pasional que podemos sentir hacia una sola persona entre muchas. [...] Amor en la forma sumaria en que lo he definido más arriba: misteriosa inclinación pasional hacia una sola persona, es decir, transformación del "objeto erótico” en un sujeto libre y único. Los poemas de Safo, no son una filosofía del amor: son un testimonio de cómo ha cristalizado este extraño magnetismo. (Paz 34)

Siguiendo el hilo de nuestra reflexión, no es casual que para referirse a la expresión de "un sentimiento de todos los tiempos y lugares" Paz tome como ejemplo a Safo, pues es precisamente en el aspecto de la cristalización “de este extraño magnetismo” que intentaremos comparar a dos de sus exponentes en el tiempo.

Poesía y AUTOBiografíA

Para hacer este trabajo comparativo hemos recurrido a dos fuentes semejantes y a la vez diferentes. Semejantes, porque ambas provienen de la poesía: de Violeta Parra sus Décimas autobiográficas, y de Safo uno de sus fragmentos poéticos. Lo diferente de ambas es que en el caso de Safo, aunque sus poemas no intentan relatar su biografía, son prácticamente el único indicio de su existencia. El caso de Violeta Parra es más complejo, pues aún existiendo mucho material escrito, entrevistas, cartas, biografías, ${ }^{2}$ las Décimas contienen algo que los otros documentos no tienen, y es que allí encontramos lo que ella quiso contar de su vida. En este sentido, el profesor y ensayista Leonidas Morales nos recuerda que los poemas de las Décimas son 'piezas' funcionales dentro de un todo argumental unitario y están al servicio del despliegue de un relato autobiográfico. ${ }^{3}$

Las Décimas, de acuerdo a lo afirmado por Morales, pertenecerían al género de la autobiografía, formando parte del género discursivo “referencial”, donde el autor y sujeto de la enunciación son el mismo (carta, diario íntimo, autobiografía, memoria, crónica, etc.) y el discurso operaría como un referente extra textual: cultural, político, biográfico. ${ }^{4}$

2 Gracias a la vida de Bernardo Subercaseaux, Patricia Stambuk y Jaime Londoño. El libro mayor de Violeta Parra de Isabel Parra. Las dos primeras, como textos de apoyo o fuente, contienen poemas de las Décimas. La tercera Violeta se fue a los cielos, constituye una mirada muy parcial, la de su hijo Ángel, tal como el mismo lo afirma.

3 Para una mayor ilustración sobre las Décimas autobiográficas de Violeta Parra ver El retorno de las Décimas de Violeta Parra de Leonidas Morales, en “Violeta Parra: la última canción”. Ed. Cuarto Propio. Santiago, 2003.

4 Morales ha denominado a éstos como géneros referenciales, afirmando que entre ellos los primeros tomados en cuenta han sido los más cercanos a los géneros “canónicamente” literarios: autobiografía, diario íntimo, por la ostensible construcción de un sujeto, porque los que los cultivas son poetas, escritores

Revista Iberoamericana, Vol. LXXVII, Núms. 236-237, Julio-Diciembre 2011, 1019-1037 ISSN 0034-9631 (Impreso) 
A pesar de que su autobiografía en verso ha servido de apoyo para los relatos que se han hecho sobre su vida, ${ }^{5}$ en nuestra reflexión tomaremos las Décimas autobiográficas como una obra poética desligándola de su potencialidad como género referencial.

\section{LOS POEMAS: EL PASO DE LA EMOCIÓN EXTREMA A SU EXPRESIÓN EN PALABRAS}

En la sección Composiciones Varias del libro Décimas. Autobiografía en verso, de Violeta Parra, aparece el poema Con mi litigio de amor (Violeta Parra ,198). Poema de amor, o más bien de ausencia de amor, éste se inscribe entre los muchos poemas que han dado expresión a las tribulaciones causadas por el estado de enamoramiento. ${ }^{6}$

El poema, dice:

Con mi litigio de amor llegué donde el señor juez, por remediar de una vez la causa de mi aflicción; le digo que en Concepción sufrí muy grande amargura que a punto de la locura me tuvo el desasosiego y al señor juez yo le ruego: senténcieme con premura.

de prestigio, aparecían integrados a la “obra”, o se erigían en "fuente” de información para su estudio. (Morales, La escritura de al lado. Géneros Referenciales.)

5 En algunas de sus biografías han sido tomados como tal, me refiero a El libro mayor de Violeta Parra y a Gracias a la Vida).

6 Aunque hemos afirmado que para este análisis no tomaremos el texto en su aspecto biográfico referencial, el que sea un poema de amor nos incita a buscar su origen extra textual, es decir, la experiencia sentimental que lo motivó. Una primera seña está dada por el poema mismo que, datado en Concepción, al parecer fue provocado por la intensa y pasional relación que la autora (hablante en el poema) tuvo en esa ciudad. En su libro Violeta se fue a los cielos, Ángel Parra nos habla de ello: "Vivía en la Escuela de Bellas Artes, un joven artista plástico de origen mapuche [...] Julio Escámez, pintor y muralista. Misterioso, tímido, oriental. Con mi madre mantenía una relación intelectual intensa ¿Tal vez algo más? Los curiosos se quedarán con las ganas, no sé nada más. A pesar de que últimamente han aparecido cronistas que cuentas historias de tercera mano. Como los implicados ya no son de este mundo es muy fácil inventarles historias" (Angel Parra, 142).

Según otras fuentes -orales-, el joven artista que dormía dentro del edificio de la Facultad de Artes, porque no tenía otro lugar donde pernoctar, no era Julio Escámez, sino el desaparecido Santos Chávez, que sí era mapuche y había sido pastor de cabras en la Araucanía, y con quien Violeta tuvo una muy importante relación intelectual, pero no amorosa. Con el que sí tuvo una breve pero intensa relación de este tipo fue con Julio Escámez, que no es mapuche, aún está vivo y habitaba entonces en un altillo en el centro de Concepción.

Revista Iberoamericana, Vol. LXXVII, Núms. 236-237, Julio-Diciembre 2011, 1019-1037 


\begin{abstract}
Mi caso tan complica'o es éste, Su Señoría, se me perdió l’alegría sin saber cómo ni cuándo, aquí me ve usted llorando con la mirada en el suelo, la vida me da recelo, m'espanta su indiferencia, la mano de la inclemencia, me ha echa'o este nudo ciego.
\end{abstract}

Ya ve mi cara, señor, más pálida que la muerte, escuche cómo de fuerte palpita mi corazón, mi pobre caparazón tirita como en invierno, mis venas son un infierno que arden en fuego mortal, castígueme el tribunal si acaso culpa yo tengo.

Es increíble y penoso lo que yo estoy padeciendo, que se me van escondiendo las ansias de hallar reposo, motivo muy doloroso el sueño me ha prohibido, la fuerza me ha consumido y me ha atormentado el alma p’a mí lo que llaman calma es vocablo sin sentido.

Si el día se me hace largo, la noche el doble, señor; con amapolas en flor consigo entrar en letargo; mi cautiverio es amargo, sus yerros aborrecibles, ya que se me hace insufrible la luna del alto cielo, y la Virgen del Carmelo no está p’a mí disponible. 
Es interesante destacar que tanto el poema de Violeta Parra como el fragmento de Safo tienen un receptor implícito: Con mi litigio de Amor está dirigido a un Señor Juez, a quien la hablante expondrá sus síntomas a fin de obtener una sentencia y terminar así su aflicción. En el fragmento 31 de Safo, la hablante se dirige, en cambio, directamente a su amada interpelándola con la descripción de su rival, al que compara a un dios por estar cerca de ella, o ser dueño de sus encantos.

Sin embargo, luego de esta primera interpelación, la fuerza y énfasis de ambos poemas se vuelca a la descripción del sufrimiento por ese estado de enamoramiento en el que se experimentan cambios físicos, se pierden los sentidos y hasta la cordura.

Es sobre este aspecto de ambos poemas que versará nuestro análisis.

LOS INICIOS DE LA POESÍA LÍRICA

La poesía amorosa o poesía lírica toma su nombre, como sabemos, de los poemas entonados al son de la lira cuando poesía y música eran una sola. Safo y Alceo (s. VI a.C) son considerados los representantes máximos de esta poesía, sin embargo es Safo la que ha sido distinguida por su perfección formal, su intensidad y la emoción de sus poemas. Citada por Herodoto, admirada por Platón y editada por los alejandrinos, en Roma su poesía fue difundida a partir de Catulo, cuyo Poema 50, a excepción de la última estrofa, es una transcripción fiel del fragmento 31. La poesía de Safo ha dado origen, desde la antigüedad, a una multiplicidad de traducciones y versiones, siendo también imitada en la literatura moderna, especialmente en la estructura sáfica, (conocido es el poema de Neruda Angela Adónica incluido en su libro Residencia en la Tierra).

La vida de Safo ha estado rodeada de leyendas y mitos, de los cuales nos habla Mary Barnard en la introducción a su traducción.7 Sin embargo, como lo afirmamos anteriormente, mucho de lo que sabemos ha llegado a través de sus poemas. Al parecer,

\footnotetext{
7 La tradición biográfica que está llena de contradicciones dice (..) Que nació en Mitylene, o en Eresus, en la misma isla. Que su fecha de nacimiento fue alrededor del 612 A.C., o antes, o después; que el nombre de su padre fue Scamandronymous, o Eurygyus, o Simon, o Eunominus, o Euarchus, o Ecrytus, o Lemus; que el nombre de su madre fue Cleis; que se casó con un comerciante de Andros, llamado Cercolas, y tuvo una hija Cleis: o, al contrario, que Cercolas es un nombre ficticio y Cleis no fue su hija; que tuvo tres hermanos, siendo uno Charaxus, que cayó en desgracia frente a su hermana cuando compró la libertad de una cortesana llamada Doriche; que Safo misma fue una prostituta; que no lo fue; que, enloquecida por su amor sin esperanzas por Phanon, un botero, se lanzó desde el acantilado de Leucadian (en una isla situada entre Itaca y Corfu); o al contrario, que murió en su lecho, en su casa, atendida por su hija Cleis (ver poema 99). Que las muchachas cuyos nombres son mencionados en los poemas -Anactoria, Atthis, Gongyla, Hera, Timas- eran sus alumnas y participaban junto a ella en las prácticas religiosas de Kallichoron Mitylene (Mitylene de las hermosas danzas); o, al contrario, que no eran tal cosa”.
}

Revista Iberoamericana, Vol. LXXVII, Núms. 236-237, Julio-Diciembre 2011, 1019-1037
ISSN 2154-4794 (Electrónico) 
vivió en el siglo vi antes de nuestra era y perteneció a una familia notable de Mitilene, capital de la isla de Lesbos. Safo habría cantado sus versos en bodas, rituales religiosos y quizás en reuniones privadas del medio aristocrático al que pertenecía. Componía en el dialecto eólico de Lesbos y no en lenguaje culto, sin embargo, Catulo la llamó "docta”. Sobre su obra, algunas investigaciones han llegado a la conclusión de que escribió 9 libros, pero de ellos -salvo la Oda a Afrodita- sólo se conservan fragmentos de poemas. ${ }^{8}$ De éstos, el que más huellas ha dejado es el fragmento 31, que es el que tomaremos en esta oportunidad. ${ }^{9}$

\section{Fragmento 31}

Es más que un héroe es un dios a mis ojos el hombre que frente a ti se sienta. Aquél, que en la intimidad escucha el dulce murmullo de tu voz, la seductora

risa que hace a mi corazón saltar dentro del pecho, pues si te miro de mi voz sólo un hilo me queda

en silencio se deshace la lengua y una llama sutil corre bajo mi piel; mis ojos nada ven, sólo escucho cómo zumban mis oídos,

8 "Fueron los filólogos alejandrinos quienes dieron orden y forma y conservaron los textos mientras hubo una tradición directa, es decir, hasta la época bizantina. Gracias a descubrimientos del siglo xx tenemos ahora un códice en pergamino del siglo viI. Sin embargo, sigue siendo invalorable la edición alejandrina en la que los poemas estaban distribuidos en nueve libros ordenados según el esquema métrico de las composiciones; el primer libro contenía las odas sáficas con cerca de 1,320 versos, es decir, 330 estrofas; el segundo, los pentámetros eólicos; y así seguían los demás libros con otros metros, pero el noveno comprendía epitalamios escritos en metros muy variados.... / Esta tradición directa que se interrumpe en la época bizantina, quedó completamente perdida hasta que en los últimos decenios, numerosos papiros y también pergaminos provenientes de Egipto nos han aportado importantes fragmentos de Alceo y Safo (hasta ahora 22 y 18 respectivamente, algunos con estimables notas)/.../ Los fragmentos de Alceo son hoy 448 y los de Safo 213”. (García Gual 145-146).

9 La versión es mía, a partir de la traducción al inglés de Mary Barnard.

ISSN 0034-9631 (Impreso) 


\begin{abstract}
me deshago en sudor, me sacuden temblores, y me vuelvo más pálida que la hierba marchita. Me parece que la muerte no está ya lejos de mí.
\end{abstract}

Hay consenso entre los estudiosos que, en este poema, la descripción del pathos amoroso alcanza la más acabada expresión, y es Longino (siglo I d.C.) en su libro $\mathrm{X}$ del Tratado Acerca de lo sublime quien nos lo ha hecho llegar al citarlo como un ejemplo, precisamente, de lo sublime:

[...] Safo por ejemplo, toma los padecimientos que corresponden al enloquecer por amor a partir de aquello que lo acompaña y de la verdad misma. ¿Y cómo manifiesta su excelencia? Porque escoge maravillosamente de entre esas cosas las culminantes y sobresalientes y las liga entre sí [...] ¿No te admira cómo a un mismo tiempo va en busca del alma, el cuerpo, el oído, la lengua, los ojos, la tez, cosas todas separadas como si fueran ajenas y, poseída por sentimientos contrarios, simultáneamente tiene frío y arde, enloquece, razona, pues (?) o teme o está casi muerta, de modo que no aparezca en ella un único padecimiento sino un conjunto de padecimientos? Todas estas cosas se dan en los que aman, pero la selección como dije, de los elementos culminantes y su reunión en un mismo todo llevaron la eminencia a su perfección. (Ingberg 68-69) ${ }^{10}$

En su artículo “El amor y el origen de la poesía”, el poeta y ensayista argentino Silvio Mattoni afirma que a partir de este poema Safo ha inventado "una intimidad, una zona de agitación interna [...], un impulso irrefrenable que parte del mismo ser que quisiera contenerse, encontrar una calma ya imposible [...] palpitaciones, imposibilidad de hablar, escalofríos, vista nublada, zumbido en los oídos, palidez. ¿Qué nombre darle a este desfallecimiento?” (Mattoni), pero la pregunta más enigmática, más irresoluble sería: “¿cómo es que podemos reconocer nosotros, todavía, estos síntomas?”, ya que, incluso hoy, los leemos como algo que puede pasarle a cualquiera.

Para el autor "una metáfora dominante ha atravesado la historia íntegra del arrebato lírico a partir de este breve fragmento, y casi parece obvia, hasta inadmisible ahora, es la idea del amor como fuego”. Metáfora que también toma Violeta en el poema de que hemos escogido:

mis venas son un infierno

que arden en fuego mortal,

10 Especialmente interesantes son los comentarios que nos ofrece Ingberg a su versión del fragmento 31;
como muchos traductores incluye al final del fragmento el verso trunco "Mas todo es soportable puesto
que...”, que ha sido omitido por otros, como es el caso de Barnard y Menéndez Pelayo. 
Al igual que en el fragmento de Safo, la gran metáfora del arrebato lírico -el fuegoestá presente en el poema de Violeta; pero, además, en ambos poemas hay otras similitudes para a expresar la "enfermedad del amor".

$\begin{array}{ll}\text { Safo } & \begin{array}{l}\text { una llama sutil corre bajo } \\ \text { mi piel; }\end{array} \\ \text { Violeta } & \begin{array}{l}\text { mis venas son un infierno } \\ \text { que arden en fuego mortal, }\end{array} \\ \text { Safo } & \begin{array}{l}\text { la seductora } \\ \text { risa que hace a mi } \\ \text { corazón saltar dentro del pecho, }\end{array} \\ \text { Violeta } & \begin{array}{l}\text { escuche cómo de fuerte } \\ \text { palpita mi corazón, }\end{array} \\ \text { Safo } & \begin{array}{l}\text { y me vuelvo más pálida } \\ \text { que la hierba marchita. Me parece } \\ \text { que la muerte no está ya lejos de mí. }\end{array} \\ & \text { ya ve mi cara, señor, } \\ \text { Vás pálida que la muerte, }\end{array}$

Analizando el fragmento de Safo, Silvio Mattoni formula una interesante pregunta “¿Cómo pasamos de la pasión, el rapto, el instante presente, que ninguna memoria registra porque ya se dejó atrás toda memoria, a la poesía, las palabras y su sentido? En otros términos, ¿̇por qué del amor surgiría la poesía?”

Acaso porque lo que se ama siempre será olvidado, porque hay una laguna textual en el centro de la descripción del instante y que es su experiencia muda, de cuya ausencia nace un ritmo, un canto previo a cualquier contenido. Toda escritura, entonces, puede representarse como un cenotafio, una inscripción sobre un cuerpo ausente. Cuando el cuerpo ya no está, y el póthos, con su sed y su engañosa saciedad, no puede confundirse con el amor, Safo vuelve a las palabras y a la medida de los versos, allí donde algo dictado, fabricado como una voz, habrá de simular aquel éxtasis, aquella dichosa y paciente salida de sí. Y en el espejo del poema se intentará descubrir no tanto el rostro amado como la propia cara del amante que escribe, que se ha olvidado del amor para escribir. Pareciera que algo perdura en el poema, entonces, como un nombre que no tiene otro sentido que su sonoridad indicando la ausencia, el borramiento intenso de una experiencia: Safo. ¿Cómo explicarme, si no, la sensación de verdad que provocan estos retazos de poemas perdidos? La persistencia de tu nombre, Safo, ¿'es una prueba? (Mattoni)

Revista Iberoamericana, Vol. LXXVII, Núms. 236-237, Julio-Diciembre 2011, 1019-1037 
Mattoni recorre las acepciones que en los lenguajes de la antigüedad clásica tuvieron las palabras pothos, eros, traducidas al castellano como deseo, amor. Hermosa y compleja es la relación que este autor entreteje a la luz de Safo, Arquiloco, Platón, Aristófanes, Diótima y hasta Dante; reflexión que a manera de síntesis recojo en esta cita:

\begin{abstract}
Si pensamos en los sentidos, frénas, en las palabras producidas por el ánimo o el pensamiento, como instancias que el deseo hace volver súbitamente al cuerpo que habían creído olvidar, entonces triunfaría la poesía en un sentido estricto: producir la belleza, mezcla de alegría y dolor, verdadero frenesí o meditación y análisis de los sentidos, pero no en general, no detrás y por encima de los seres mortales, sino aquí y ahora, precisamente porque van a morir y no tendrán resurrección ni alas, salvo en este instante en que las generan en algún otro. (Mattoni)
\end{abstract}

“La relación entre amor y poesía no es menos sino más íntima”, afirma Octavio Paz en "La llama doble", aludiendo también al fragmento 31 como un ejemplo de expresión de la emoción al contemplar al ser amado.

Primero la poesía lírica y después la novela -que es poesía a su manera- han sido constantes vehículos del sentimiento amoroso. Lo que nos han dicho los poetas, los dramaturgos y los novelistas sobre el amor no es menos precioso y profundo que las meditaciones de los filósofos. Y con frecuencia es más cierto, más conforme a la realidad humana y psicológica. Los amantes platónicos, tal como los describe El Banquete, son escasos; no lo son las emociones que, en unas cuantas ínea, traza Safo al contemplar una persona amada. (Paz 49-50)

El paso de la intensa e inefable emoción a su perfecta expresión en palabras, sólo podría lograrlo la poesía; y a grandes rasgos este es el atributo que permite una cercanía entre las dos poetas.

Nos hemos referido anteriormente a la influencia que, especialmente, el fragmento 31 ha tenido en obras posteriores, de allí surge entonces la pregunta ¿Podría el poema Con mi litigio de amor ser una recreación del fragmento 31? O en términos más generales: Violeta Parra ¿habría leído a Safo? Varios testimonios nos indican que Violeta fue autodidacta, que sus lecturas fueron escasas, ${ }^{11}$ por lo que no es muy probable que haya leído a la poeta griega. En una entrevista hecha a Nicanor Parra por el crítico Leonidas Morales, éste expresa una opinión acerca de las lecturas de Violeta.

\footnotetext{
11 "Aprehendiendo una vasta riqueza aun no suficientemente desenterrada ni conocida, a través de la función recopilatoria de la relatora Violeta Parra, el decantamiento de toda esa experiencia tardaría años en brotar como un producto personal y artísticamente madurado. Eso fue lo único que constituyó el auténtico aprendizaje de ella, oponiéndose con razón o sin razón, a la solitaria meditación del artista culto” (Campos 55).

Revista Iberoamericana, Vol. LXXVII, Núms. 236-237, Julio-Diciembre 2011, 1019-1037 \begin{tabular}{l} 
ISSN 2154-4794 (Electrónico) \\
\hline ISSN 0034-9631 (Impreso)
\end{tabular}
} 
[...] Leyó poco. Ella no tuvo una debilidad por leer novelas tampoco. Algo leyó, ¿ah?, pero literatura más bien de desecho. Yo creo que ni al propio Neruda le conoció a fondo. Claro, conoció necesariamente en el colegio a la Mistral, en los libro de lectura llegaba algo de Magallanes, de algunos poetas del primer modernismo chileno. Eso necesariamente. Y además yo estaba todo el tiempo leyendo en voz alta también, decía cosas, y todo eso pasaba automáticamente a ella. [...] Pero ella no fue una estudiosa como he sido yo de la literatura francesa, por ejemplo. No sé si conoció la palabra Rimbaud, la palabra Baudelaire. (Morales, Conversaciones con Nicanor Parra 153)

Ampliando la imaginación podríamos elucubrar que tal vez en París pudo haberle llegado, de oído, alguna de las tantas versiones del fragmento $31,{ }^{12}$ pero la posibilidad más certera es que Violeta no haya conocido el poema de Safo ni sus versiones. La pregunta obligada es, entonces ¿cómo llegan dos mujeres separadas por 27 siglos y en contextos, idiomas y entornos diferentes a expresar la intensidad de sus emociones en forma tan similar?

Esta pregunta nos remite a otra: ¿de qué manera, a través de los siglos, se han leído los signos de este algo "que puede pasarle a cualquiera”, es decir, del enamoramiento?

Para María Esther Martínez, uno de los hitos -y a la vez uno de sus valoreses la "veracidad" de las Décimas. Al ser la autobiografía de una mujer concreta que expone su vida privada y pública, sus relaciones con el mundo -y especialmente sus sentimientos-, sus imágenes entrarían en la categoría de imágenes universales, o en "metáforas de la mujer heterosexual de todos los tiempos y espacios" (Martínez, 2). De acuerdo a esta autora

Las Décimas tienen una marca femenina y deben estudiarse como tal [...] La personalidad cálida y vigorosa de Violeta Parra se destaca en las Décimas con un sello inconfundible de humanidad que hace al lector sentir que su experiencia se ahonda sin falsos pudores. Es la historia fuerte y valiente de las mujeres que luchan y se levantan por su propio esfuerzo, sin doblegarse jamás. (Martínez 4)

VIOLETA: TRADICIÓN E INNOVACIÓN DE LA POESÍA POPULAR

Otro de los hitos que destacan a Violeta Parra es su singular vínculo con la poesía oral y popular. En sus composiciones Violeta revive-tomando de los cantores populares con los que conversó y a los que grabó- muchas de las formas del canto trovadoresco, entre ellos la canción de contenido amoroso, el entredicho y el sirventencio, este último

${ }^{12}$ Solamente en francés, Philippe Brunet ha recopilado 100 versiones de este fragmento, que van desde Louise Labé (1555); Racine, en Phèdre, I,3 (1677); Marguerite Yourcenar, La couronne et la lyre (1979) hasta Michèle Grangaud y el mismo Philippe Brunet en los 90’.

Revista Iberoamericana, Vol. LXXVII, Núms. 236-237, Julio-Diciembre 2011, 1019-1037 ISSN 0034-9631 (Impreso) 
utilizado tradicionalmente para la acusación moral, pero hoy tomado especialmente para la denuncia política.

Su delicada forma de hacer canciones utilizando métricas establecidas por la tradición, el encadenamiento de las estrofas, la elección de las melodías y el rigor en la función de cada canto, entre otras características de los troveros, si bien la sitúa como cantora, según su funcionalidad en tanto representativa de la comunidad chilena, específicamente campesina, se evidencia fuertemente como figura central de una nueva forma de concebir la canción en concordancia con la primigenia representación del género. (Díaz Inostroza)

La investigadora Silvia Lafuente ya había destacado la particularidad de las Décimas de Violeta, que, si bien siguen la tradición folclórica, están impregnadas de su propia creación.

El concepto de autonomía y al mismo tiempo de influjo recíproco en las relaciones entre folclore y literatura coexisten en las Décimas de Violeta Parra. La obra presenta un código artístico (folclórico) bien identificable tanto en lo que se refiere a algunos temas y motivos como a la forma. Pero al mismo tiempo se trata de un texto escrito, de autor conocido e individualizable, que no ha sufrido el largo y complejo proceso de folclorización y en cuya narración no está presente el estilo de la tradición oral. Pero el caso de esta obra es sin embargo particularísima. Dentro de la misma hay un espacio auténticamente folclórico, Violeta se inserta en una forma colectiva donde encuentra ya los módulos: formas métricas y estrofas características, temas y expresiones a los que su poesía se adaptan. Ella recrea, en este caso, una poesía que en líneas generales ya ha sido previamente elaborada, sin modificar las normas, adaptándose a la uniformidad y rigidez de la creación colectiva. [...] En otros momentos de la obra elaborando ella misma el lenguaje, imprimirá al material recibido la huella de su propia personalidad artística. La norma folclórica se convertirá en innovación individual. (Lafuente 57-58)

Afirmando esta tesis, en su libro Violeta Parra: la última canción, Leonidas Morales dice que "Violeta le da a su relato autobiográfico, fingidamente desde luego (o retóricamente, en el buen sentido del término) el marco propio de la comunicación de los poetas del folclor, es decir, el del "canto" de los versos [...] refuerza la idea de oralidad dirigiéndose, no a un lector, sino a los "señores oyentes” (Morales 57). Pero estas huellas del folclor presentes en las Décimas, tienen una gran diferencia con las letras de sus canciones, que sí se insertan en la tradición oral

[...] las marcas de oralidad y el canto en las Décimas son evidentes y saltan por todas partes. Pero estas marcas, incluida la del poeta-cantor, que es sólo una figura literaria destinada al sentido del relato [...] son aquí el aparejo de un lenguaje cuyo

Revista Iberoamericana, Vol. LXXVII, Núms. 236-237, Julio-Diciembre 2011, 1019-1037 ISSN 0034-9631 (Impreso) 
rasgo dominante, estructural, es otro [...] Al revés de las letras de las canciones, los poemas de las Décimas fueron escritos para ser leídos. Destinados a un lector y no a unos "señores oyentes". Por eso mismo son también, de todos los que forman la poesía de Violeta, los más literarios. Tienen, en oposición a las letras, la densidad minuciosa, desarrollada, analítica, y el artificio (en la acepción no peyorativa del término) característicos de la poesía que es escritura. (Morales 62)

En el estudio Décimas autobiográficas de Violeta Parra: Tejiendo diferencias, Paula Miranda, por su parte, afirma que a pesar de estar obligada por dos tradiciones estéticas que imponen sus reglas -la autobiografía y la décima- Violeta está inventando cada día un arte nuevo.

Hay allí una doble imposición, temática y formal, que Violeta productivizará al máximo. No es posible decir que ella entre en el discurso dominante o en el orden simbólico del padre en forma conflictiva, o teniendo que optar en forma excluyente entre el sometimiento o el silencio. Eso no haría más que confirmar la teoría de que toda escritura de mujeres es el hueco, el no-lugar. En la superficie textual de las décimas Violeta entra en los discursos impuestos en forma sutil y ecléctica, voluntaria y gozosa. (Miranda)

Hay consenso entonces en que, luego de su etapa de recopiladora y sin perder los rasgos de la "vers’á popular", Violeta da el salto hacia una poesía autobiográfica que testimonia su época, pero también describe las penurias de su vida y, en forma magistral, sus más fuertes sentimientos.

\section{SAFO: VISIÓN DEL MUNDO DESDE LO FEMENINO}

La poesía de Safo ha sido considerada innovadora porque propone, ya en el siglo vi a.C., una visión de mundo desde lo femenino, oponiendo su mirada a la de los cantores masculinos cuyos sentimientos estaban dirigidos hacia una exterioridad. A diferencia de sus contemporáneos, Safo interioriza la concepción del sentimiento dirigiéndose a un mundo personal en el cual el otro es, generalmente, una mujer. La obra de Safo se ha leído también como la expresión de una sexualidad femenina activa, a diferencia de la figura de la mujer como objeto pasivo del deseo.

Según el poeta Juan Gelman, Safo estaría alterando las pautas culturales dominantes en materia de sexualidad y de género: "es decir, la heterosexualidad y/o esa relación homosexual entre adultos y efebos que Platón reveló sin sobresaltos y que, en realidad, giraba en torno a las cuestiones de poder y de control masculinos en la antigua Grecia. Los versos de Safo cuestionan esa sociedad jerarquizada, tal vez sin proponérselo” (Gelman 70). Esta lectura de la obra de Safo desvirtúa la visión

\footnotetext{
Revista Iberoamericana, Vol. LXXVII, Núms. 236-237, Julio-Diciembre 2011, 1019-1037
ISSN 2154-4794 (Electrónico)
} 
generalizada que se tiene de la Grecia del siglo vi a.C. como un mundo masculino de guerras, héroes y épica. Con un espacio íntimo, sensible y pasional, Safo irrumpe en esa Grecia clásica, descubriendo los símbolos de un imaginario femenino.

SAFo, Violeta. La EXPRESión DEL AMOR

El amor -con su fuerza creadora, con el dolor que significa la pérdida, en todos sus matices- es la experiencia humana que ha dado origen tal vez al mayor número de canciones de Violeta Parra. Pupila de águila; Run Rún se fue p’al norte; Maldigo del alto cielo, incluidos en sus Ultimas composiciones (1966), junto a Gracias a la vida, son las canciones que han quedado grabadas con más fuerza en nuestra memoria, por estar dedicadas, seguramente, a la pérdida de su o sus últimos amores. Sin embargo las canciones de amor y mal amor ya estaban presentes en su producción primera.

Así lo muestran estos fragmentos de sus composiciones:

Los celos me oprimen

Yo no sé por qué

¿por qué no te vienes

conmigo otra vez?

(Me voy, me voy)

Como no tengo palabras,

que aclaren mi corazón,

te mandaré por el aire,

el hueco de mi canción,

en ella va dibujada,

la forma de mi pasión.

(Qué Palabra Te Dijera)

Te has ido, dejando a ciegas mis ojos,

Me quedo en las tinieblas sin tu amor.

¿Será la maldición que nos persigue,

Será ése el destino de los dos?

(Escucha mi Ruego)

En cuanto a Safo, ${ }^{13}$ se sabe que fue el centro de un grupo de muchachas

13 “Ella fue directora y cabeza de una institución que educaba a jovencitas, pero de acuerdo a las costumbres de la época dicha institución tenía un carácter especial. Era, tal como ella lo nombra, un moisopolon

Revista Iberoamericana, Vol. LXXVII, Núms. 236-237, Julio-Diciembre 2011, 1019-1037 
estrechamente unidas a ella y que Atis, Góngula, Anactoria son algunas de las destinatarias de sus poemas amorosos, poemas que, además de su fina y exacta expresión, tienen la particularidad de estar escritos en un discurso directo y coloquial

\author{
Temerosa \\ de perderte \\ corrí aleteando como una niñita \\ detrás de su madre
}

Gracias,

querida mía,

viniste,

e hiciste bien en venir: te necesitaba,

has hecho arder el amor en mi corazón

-ibendita seas! te bendigo tanto

como interminables me han parecido las horas

mientras no estabas.

Fui tan feliz

créeme,

rogué para que esa noche

fuera doble

para nosotras.

$(\mathrm{F} .47)^{14}$

Es también esta forma directa para expresar sus emociones, la que otorga proximidad a la poesía amorosa de ambas, proximidad que es aún más notable en los poemas elegidos para este artículo: Con mi litigio de amor y el fragmento 31 describen las consecuencias físicas que tienen en su cuerpo -aquí y ahora, no en la ensoñación- la

domos, una casa de aquellas que cultivaban las Musas; pero era mucho más que una escuela o una asociación ocasional de niñas con un propósito religioso. Estaba vinculada primordialmente al culto de Afrodita, y sus miembros formaban un thiasos, parecido al de Eresus, -que excluía a los hombres- o a la compañía de mujeres en Paros, unidas en el culto de Afrodita Oistro. El thiasos de Safo no era el único en su tipo en Mitylene. Los otros eran controlados por sus rivales Gorgo y Andrómeda, y las relaciones de Safo con ellas no eran de carácter amistoso”. Bowra, C.M. en Mary Barnard op. Cit. p. 112 (La traducción al castellano es mía.).

14 La numeración de los fragmentos es la utilizada por Mary Barnard. La versión castellana es mía, a partir de la traducción al inglés de M. Barnard.

ISSN 0034-9631 (Impreso) 
presencia, la ausencia o los celos provocados por la persona amada. Safo y Violeta hablan en sus poemas de la pasión amorosa como una fuerza irracional que se apodera del ser humano manifestándose en forma de deseo, celos o una inexplicable melancolía. La diferencia de sexo del destinatario o destinataria no hace gran diferencia respecto a la forma de expresar la fuerza y profundidad de su exaltación y penurias. Es verdad que la poesía de Safo puede ser más aristocratizante, sin embargo aún en la estrofa popular, Violeta alcanza la perfección a la que se refiere Longino.

Retomamos el punto de partida de esta reflexión: el amor como sentimiento extremo ha intentado ser abordado por los discursos intelectuales, pero siendo por sobre todo una experiencia, y tan paradójica en sus síntomas, no puede sino ser recogida por un lenguaje que contenga en sí la paradoja: el lenguaje poético, o más bien, la poesía en su estricto sentido: “...mezcla de alegría y dolor, verdadero frenesí o meditación y análisis de los sentidos” (Mattoni). Los poemas de Safo, -como ha dicho Octavio Pazy los de Violeta, agregamos, no son una filosofía del amor: son un testimonio de cómo ha cristalizado en palabras este "extraño magnetismo" que atraviesa todos los tiempos.

Como hemos afirmado anteriormente, está claro que hay entre los dos poemas grandes diferencias en su forma, lenguaje, ritmo, etc. Todas ellas provienen de la multiplicidad de factores culturales que las separan: el entorno poético de elite en que se movía Safo, la tradición poética de las escuelas y su cultivo desde jóvenes del arte de cantar y poetizar en el culto a la diosa Afrodita. En el caso de Violeta, su filiación con la poesía y el canto popular, su voluntad de reinsertar el folclor campesino perdido en un mundo urbano. Sin embargo, hemos visto también que en ambas hay un intento de rebeldía frente a una situación cultural dada. En el caso de Safo, la presencia de una poesía amorosa intimista, que se aparta de la exterioridad de los cantos épicos. En el caso de Violeta, su férrea voluntad de retomar los cantos tradicionales del campo e insertarlos en la ciudad reinventando el folclor, así como su abierta rebeldía ante una situación política y social injusta que la hace ser testimonio de una época. De distinta forma, también podemos ver a través de la poesía de ambas, la particularidad de su ser mujer: en un ambiente aristocratizante y exclusivamente femenino en una, y en un ambiente de carencias y dificultades tanto para sobrevivir como para obtener sus fines, la otra.

Esto, en términos generales, pero ¿qué podríamos decir concretamente en cuanto a la relevancia cultural de ambos poemas? ¿Qué los hace diferentes de otros poemas de amor? Volvemos a las palabras de Longino destacando la excelencia del fragmento de Safo: “¿No te admira cómo a un mismo tiempo va en busca del alma, el cuerpo, el oído, la lengua, los ojos, la tez, cosas todas separadas como si fueran ajenas y, poseída por sentimientos contrarios, simultáneamente tiene frío y arde, enloquece, razona, pues o teme o está casi muerta, de modo que no aparezca en ella un único padecimiento sino un conjunto de padecimientos?”

\footnotetext{
ISSN 2154-4794 (Electrónico)
ISSN 0034-9631 (Impreso)
} 
Aunque con lenguaje distinto, son estas "cosas separadas como si fueran ajenas" las que toma Violeta para dar cuenta de su "conjunto de padecimientos". "Todas estas cosas se dan en los que aman”, dice Longino, "pero la selección (...) de los elementos culminantes y su reunión en un mismo todo llevaron la eminencia a su perfección”. Violeta posee la sutileza y agilidad para lograr la perfección, su perfección, encontrando las palabras y el tono preciso para decir lo que siente en ese momento especial. Y es este gesto -este don- lo que hace comparables a dos autoras tan diferentes y lejanas: la precisa, osada y a la vez sutil expresión de profundos y contradictorios pensamientos que pueden unir íntimamente amor, poesía y vida -o muerte- llevando, a veces, a la decisión más drástica y libre del ser humano: terminar con su vida. Esta fue la decisión que tomó Violeta, su tristeza -por la pérdida- la podemos leer en este poema:

$$
\begin{aligned}
& \text { Aquí voy con mi canasta } \\
& \text { de tristezas a lavar } \\
& \text { al estero del olvido } \\
& \text { dejen, déjenme pasar. } \\
& \text { Tu cariño fue un rebozo } \\
& \text { que nos abrigó a los dos } \\
& \text { lo manchaste una mañana } \\
& \text { cuando me dijiste adiós. }
\end{aligned}
$$

En cuanto a Safo, una de las leyendas afirma que se habría suicidado por amor a Faón lanzándose desde un acantilado. Sin embargo, por lo encontrado en sus papiros, se cree que murió en su casa, al lado de su hija Cleis, según leemos fragmento 150.

$$
\text { ¿Debo recordarte, Cleis, }
$$

Que los sonidos de la aflicción

son indignos

en la casa de un poeta?

¿Y que tampoco son

apropiados en la nuestra?

No tengo quejas

La prosperidad que

las musas doradas

me otorgaron

no fue ilusión:

muerte, no voy a ser olvidada.

ISSN 0034-9631 (Impreso) 
Este último verso habla de permanencia: vencer, por medio de la poesía, el olvido causado por la muerte corporal, lo que también ocurre con Violeta: su obra -música, poesía, arpilleras, pintura- la hace permanecer viva a través de los años.

Poesía que, tal vez, sea la línea que “teje de otra forma los calendarios”, porque terminaremos este trabajo con una reflexión que nos permitiría afirmar, desde otro lugar, la cercanía de estas poetas no en el tiempo, sino en un espacio de simultaneidad. Es el espacio del "sentimiento de amor" del que habla Juan Emar, o más bien, su narrador en Umbral:

Sentía que los calendarios deberían ser tejidos por otras líneas de diferentes significados; no deberían ser regidos como hasta hoy lo son, por el nacimiento y muerte de los hombres. Esta manera de tejer y regir, echa hacia atrás a muchos hombres, a muchos sentimientos e intenciones; y, por equivalencia, echa otro tanto hacia un adelante sin existencia. De modo que un sentimiento de amor, por ejemplo -sentimiento único y permanente-, queda de pronto partido en dos: una parte allá en lo que aún no es pues faltan muchos siglos que correr [...] Todo esto, en mi más profunda intimidad, me parecía falso, ilusorio. Es nula esa separación entre esas dos partes del sentimiento. Existía para ambas un punto de simultaneidad y este punto se asentaba en la permanencia [...] Amor remoto y amor futuro estaban, eran juntos [...] (Emar 14)

\section{BiBLIOGRAFÍA}

Barthes, Roland. Fragmentos de un discurso amoroso. Buenos Aires: Siglo Veintiuno editores, 2002.

Brunet, Philippe. L'Egal des dieux. Cent verisions d'un poème de Sappho. París: Editions Allia, 2004.

Campos, Javier. "Lecturas de las Décimas de Violeta Parra”. Cuadernos Hispanoamericanos. Los Complementarios 5 (mayo 1990).

Díaz-Inostroza, Patricia. "La poesía trovadoresca en la canción popular chilena”. Rev. music. chil. (online) LIV/194 (Santiago, jul. 2000).

Emar, Juan. Umbral. Primer pilar. Carlos Lohlé, ed. Buenos Aires, México, 1977.

García Gual, Carlos. Antología de la poesía lírica griega. Siglos VII-IV A.C. Madrid: Alianza Editorial, 1980.

Gelman, Juan. Miradas. ERA, 2006.

Kristeva, Julia. Historias de amor. siglo XXI editores s.a., 1993.

Lafuente, Silvia. “Folklore y literatura en las Décimas de Violeta Parra”. Cuadernos Hispanoamericanos. Los Complementarios 5 (mayo 1990): 57-58.

Martínez, María Esther. "Las Décimas de Violeta Parra: Del Yo Individual a lo Universal”. <www.archivochile.com/Cultura_Arte_Educacion/vp/s/ vpsobre0018.pdf>

Revista Iberoamericana, Vol. LXXVII, Núms. 236-237, Julio-Diciembre 2011, 1019-1037 ISSN 0034-9631 (Impreso) 
Mattoni, Silvio. "El amor y el origen de la poesía”. <www.elinterpretador. net/18SilvioMattoni-ElAmorYElOrigenDeLaPoesia.htm-81k>. Artículo aparecido anteriormente en Nombres, revista de filosofía 19 (Córdoba, abril 2005).

Miranda, Paula. “Décimas autobiografiadas de Violeta Parra. Tejiendo diferencias”. $<$ www.cyberhumanitatis.uchile.cl/13/index.html $>$.

Morales, Leonidas. Conversaciones con Nicanor Parra. 1990. Santiago: Tajamar Ediciones, 2006. 153.

La escritura de al lado. Géneros Referenciales. Santiago: Cuarto Propio, 2001. Violeta Parra. La última canción. Santiago: Cuarto Propio, 2003.

Parra, Violeta. Décimas. Autobiografía en verso. Santiago: Sudamericana, 1998.

Paz, Octavio. La llama doble. Amor y erotismo. Barcelona: Seix Barral, 1993. 49-50. Sappho. A translation by Mary Barnard. Boston: Shamhala Pocket Classics, 1994.

Safo. Poesía lírica de la antigua Lesbos. Santiago: Ril Ediciones, 1997. 68-69.

\section{LECTURAS}

Bataille, Georges. El erotismo. Barcelona: Ed. Mateu, 1971.

Catulo. Poesía completa (C.Valerii Catulli Carmina). Versión castellana y notas de Juan M. Rodríguez Tobal. Poesía Hiperión. 2a . Ed. Madrid, 1993.

Ibn Hazm de Córdoba. El Collar De La Paloma. Tratado sobre el Amor y los Amantes. Prólogo de José Ortega y Gasset. 2a . Ed. Sociedad de Estudios y Publicaciones. Madrid, 1967.

León, Fray Luis de. Cantar de los Cantares, en Obras Completas Castellanas. Madrid: Biblioteca de Autores Cristianos, MCMLI.

Ovidio Nason, Publio. Arte de amar. Juan Manuel Rodríguez Tobal, trad. y notas. Madrid: Ed. Hiperion, S.L., 2002.

Parra, Isabel. El libro mayor de Violeta Parra. Madrid: Meridion, 1985.

Parra, Angel. Violeta se fue a los cielos. Catalonia, 2006. 142-143.

Platón. El banquete en “Diálogos socráticos”. Estudio preliminar de Ángel Vassallo. Conaculta Océano. México.

Rougemont, Denis de. El amor y occidente. Ed. Kairos. 1993.

Safo. Poemas y fragmentos. Versión castellana y notas de Juan Manuel Rodríguez Tobal. Poesía Hiperión. 2a . Ed. Madrid. 1993.

Antología. Aguilar. Introducción, selección, versión y notas de Manuel Rabanal Álvarez. Avila. 1963.

Grijalbo Mondadori. Madrid. 1998.

Subercaseaux, Bernardo, Patricia Stambuk y Jaime Londoño. Gracias a la vida, Violeta Parra, testimonio. Santiago: Editorial Granizo/Ceneca, 1982.

Varios autores. El Kamasutra de Vatsyayana. José J. de Olañata, ed. 2009.

Revista Iberoamericana, Vol. LXXVII, Núms. 236-237, Julio-Diciembre 2011, 1019-1037 ISSN 0034-9631 (Impreso) 
